\title{
UNIVERSITY OF MICHIGAN RADIOCARBON DATES VI
}

\author{
H. R. CRANE and JAMES B. GRIFFIN* \\ The University of Michigan, Ann Arbor, Michigan
}

The following is a list of radiocarbon dates obtained since the preparation of the manuscript for the publication of Michigan V, in December, 1959. The method of measurement and treatment of data are the same as those described in the introductions to Michigan lists III and IV. A full statement on the Michigan counter is referred to by Crane (p. 46) in this issue.

We acknowledge the help of Patricia Dahlstrom for the chemical preparation of the samples and of Alan L. McPherron and George J. Armelagos in the preparation of descriptions. We are indebted to the Michigan MemorialPhoenix Project for the major part of the financial support of the laboratory.

\section{SAMPLE DESCRIPTIONS}

\section{GEOLOGIC SAMPLES}

\section{A. Central U.S.}

\section{M-1138. Saginaw, Michigan}

Northern white-cedar log from floor of a buried forest, found in a clay pit being excavated to make a private fish pond $\left(43^{\circ} 25^{\prime} \mathrm{N}\right.$ Lat, $84^{\circ} 00^{\prime} \mathrm{W}$ Long), Saginaw County, Michigan. Sample, probably drowned by rising Lake Nipissing at alt $572 \mathrm{ft}$, was buried with other forest materials beneath $18 \mathrm{ft}$ of silty clay, in an ancient erosion notch in the bank of Tittabawasse River. The overlying silt shows no clear indication of intervening dry periods and suggests continual filling of the pond. Coll. August 1960 and subm. by Mark Papworth, Museum of Anthropology, Univ. of Michigan. Comment: date suggests that Nipissing rose rapidly and evenly to $605-\mathrm{ft}$ level. Nearby Andrews site has an occupation at $592.2 \mathrm{ft}$ alt, dated $5300 \pm 300$ (M-94l, Michigan V, p. 34), which was covered by Nipissing water. The Andrews site was re-occupied at $3170 \pm 300$ (M-659, Michigan V, p. 34) on what was probably a shore of Zumberge Zee, a Univ. of Michigan name for a large embayment of Lake Algoma time, SW of Saginaw Bay.

\section{M-653. Williams Farm, Michigan}

Wood, subm. by E. P. Gibson, Grand Rapids, Michigan, from the Williams farm, located ca. $.25 \mathrm{mi}$ from Flat River $\left(43^{\circ} \mathrm{l}^{\prime} \mathrm{N}\right.$ Lat, $85^{\circ} 17^{\prime} \mathrm{W}$ Long), Otisco Township, Ionia County, Michigan. The specimen, found in 1877 during digging of a well, was located at depth of $87 \mathrm{ft}$, below a layer of $50 \mathrm{ft}$ of blue clay. Comment: a pre-Wisconsin tree fragment, deeply buried by drift.

\section{M-855. Mackinaw City, Michigan}

$5270 \pm 300$

Root end of hemlock log from $2400 \mathrm{ft} \mathbb{W}$ of the shore of Straits of Mackinac and $225 \mathrm{ft} \mathrm{W}$ of approach to Mackinac Bridge $\left(45^{\circ} 46^{\prime} 35^{\prime \prime} \mathrm{N}\right.$ Lat, $84^{\circ}$

\footnotetext{
* The authors of this paper wish to register their protest at the editorial policy, common to most geologic journals, that dictates deletion, wherever possible, of al from such words as geologic and archaeologic.
} 
$44^{\prime} 00^{\prime \prime} \mathrm{W}$ Long), Emmet County, Michigan. Log lay horizontal in sandy gravel at alt $597 \mathrm{ft}$, covered with ca. 6 or $7 \mathrm{ft}$ of sediment. Soil at this site mapped as Alpena Cobbly loam (Foster and Shearin, 1939). Gravel extends several $\mathrm{ft}$ below the log. Beneath gravel is gray silt and clay (possibly marly), underlain by red clay (possibly varved). Bedrock (limestone) appears to lie at $25 \mathrm{ft}$ depth. Many other buried logs are reported ca. 4 or $5 \mathrm{ft}$ lower than the log sampled. Coll. June 1957 and subm. by R. W. Kelley, Geol. Survey Div., Lansing, Michigan. Comment: sample was exposed for $6 \mathrm{yr}$.

\section{M-855A. Mackinaw City, Michigan, fresh sample $\quad \mathbf{5 6 5 0} \pm 300$}

Fresh sample of log from which M-855 was taken. M-855A had not been exposed to the air. Coll. May 1958 and subm. by R. W. Kelley, Geol. Survey Div., Lansing, Michigan. Comment: much of original ground surface has been stripped and it is unlikely that much new information can be obtained in the field. A study of air photos and alt of the log give some credence to the idea that the feature was a beach of Lake Algoma. $\mathrm{C}^{14}$ date indicates this tree lived during the Stanley-Nissing transition. It appears likely that the hemlock inhabited the lacustrine plain abandoned by Lake Algonquin and was knocked down and buried by action of rising water, prior to Nipissing stage.

\section{M-968. Stonington Peninsula, Michigan $\quad \mathbf{5 7 2 0} \pm \mathbf{2 5 0}$}

Wood from pit, ca. $500 \mathrm{ft}$ from high-water line of Lake Michigan, along the $\mathrm{E}$ to $\mathrm{W}$ center line of sec. $33\left(45^{\circ} 49^{\prime} 10^{\prime \prime} \mathrm{N}\right.$ Lat, $86^{\circ} 46^{\prime} 40^{\prime \prime} \mathrm{W}$ Long), Stonington Peninsula, Delta County, Michigan. Log from which specimen was cut was uncovered at depth of 7 to $8 \mathrm{ft}$. Bottom of pit was limestone bedrock, overlain by $\mathrm{l}$ to $1.5 \mathrm{ft}$ of gray clay. Clay was overlain by a dark soil, $1-\mathrm{ft}$ thick, in which the wood was located. Soil zone was overlain by ca. $5 \mathrm{ft}$ of sand. Surface elevation is $600 \mathrm{ft}$ above sealevel. Dark soil is ca. $5 \mathrm{ft}$ above present Lake Michigan, as measured by aneroid harometer. Coll. March 1959 and subm. by A. E. Slaughter, Geol. Survey Div., Escanaba, Michigan. Comment: location is ca. $25 \mathrm{ft}$ below shoreline of Lake Nipissing (M-855, M-855A, M-1012 and M-1138, this list).

\section{M-1012. Thompson's Harbor, Michigan}

Charred wood from two separate stumps in situ on lake bottom at depth of $15 \mathrm{ft}$ below the surface in Lake Huron, $300 \mathrm{yd}$ from the mouth of Thompson's Harbor, SE of Rodgers City (ca. $44^{\circ} 23^{\prime} \mathrm{N}$ Lat, $83^{\circ} 36^{\prime} \mathrm{W}$ Long). Michigan. This alt is ca. $175 \mathrm{ft}$ below Algonquin beach. It is supposed that the trees were covered by water rising from the Chippewa-Stanley low level of the Huron basin and that fire had occurred before that time. Coll. by D. R. Brackenbury, Geol. Survey, Mt. Pleasant; subm. by J. H. Zumberge, Univ. of Michigan. Comment: see also M-834 (7850 \pm 350 , Michigan V) for sample of drowned organic material in Lake Michigan hasin, ca. $155 \mathrm{ft}$ below Lake Algonquin.

\section{M-694. Elkhart, Indiana}

$9320 \pm 400$

Bone from American mastodon (Mammut americanus Kerr) found 2 mi due $\mathrm{W}$ of freight office at Elkhart $\left(41^{\circ} 44^{\prime} \mathrm{N}\right.$ Lat, $86^{\circ} 59^{\prime} \mathrm{W}$ Long $)$, Indiana. 
Sample found in marl below $16 \mathrm{ft}$ of muck and peat. Coll. January 1957 by Scott Talbot; subm. by C. W. Hibbard, Univ. of Michigan. Comment: the date seems reasonable.

\section{M-936. Val-Lor-Will Farm, Wisconsin}

Log, id. as spruce by J. M. Dryn, from Val-Lor-Will farm $\left(42^{\circ} 32^{\prime} 55^{\prime \prime}\right.$ $\mathrm{N}$ Lat, $88^{\circ} 30^{\prime} 30^{\prime \prime} \mathrm{W}$ Long), Walworth County, Wisconsin, from morainal deposits on $\mathrm{S}$ side of Lake Geneva. Sample, probably transported by ice, lay depth of 18 to $20 \mathrm{ft}$ in Darien terminal moraine of Cary age, as mapped by Alden (1918). Coll. September 1957 by Robert Schramski; subm. by R. F. Black, Univ. of Wisconsin, Madison. In spite of the mapping by Alden, the deposits seem to be older than Cary when weathering and surface expressions are compared with Valparaiso Moraine of Illinois or Kettle Interlobate Moraine of Wisconsin. Comment: sample of same $\log , \mathbb{W} \cdot 638$, was dated $31,800 \pm 1200$ (USGS V).

\section{M-1067. Lloyd's Rock Hole, Pennsylvania $\quad 9540 \pm \mathbf{5 0 0}$}

Small mammal bones, mostly hare (Lepus americanus), from Lloyd's Rock Hole, $1.5 \mathrm{mi}$ NE of New Paris $\left(40^{\circ} 7^{\prime} \mathrm{N}\right.$ Lat, $78^{\circ} 37^{\prime} \mathrm{W}$ Long), Bedford County, Pennsylvania. Specimen found 17.5 to $21.5 \mathrm{ft}$ below mouth of sinkhole. Coll. 1959 by A. D. McCrady and R. R. Bossart, Carnegie Museum, Pittsburgh, Pennsylvania; subm. by J. E. Guilday, Carnegie Museum. Should date an associated fauna of 53 vertebrates and 12 invertebrates (Guilday and Bender, 1958) and an associated pollen profile. Fauna and flora are boreal in character and late Pleistocene in age. Date should provide a minimum terminal date for the Pleistocene peccary, Mylohyus, and a basis for correlation with other Appalachian cave faunas, similar in species composition but unrelated to any particular stage of the late Pleistocene. The $\mathrm{C}^{14}$ run on this specimen was somewhat shorter than normal 48-hour period. Comment: the date is slightly later than expected.

M-1103. Jones local fauna, Kansas

Fossil snails from Jones local fauna $\left(37^{\circ} 14^{\prime} \mathrm{N}\right.$ Lat, $100^{\circ} 16^{\prime} \mathrm{W}$ Long), Meade County, Kansas. Sample was from a l-ft thick measured section taken from bed no. 5, Jones Sink, Vanhem Formation, Meade County, loc. 13. Coll. summer of 1955 and subm. by C. W. Hibbard, Univ. of Michigan. Comment: considered Late Wisconsin in age. See Downs $(1949 ; 1954)$ and Tihen (1942) for description of the fauna.

M-832. Butler Spring, Kansas

$40 \pm 150$

Wood (cedar ?) from depth of $2 \mathrm{ft}$ in Butler Spring $\left(37^{\circ} \mathrm{N}\right.$ Lat, $100^{\circ}$ $26^{\prime} \mathrm{W}$ Long), SW 1/4 sec. 33, T 34S, R 29W, Meade County, Kansas. Coll. July 1941 by Henry Cochran and C. W. Hibbard; subm. by Hibbard, Univ. of Michigan. Specimen was coll. because there were no growing trees or stumps in this area when settled by Cochran in 1905 .

M-854. Montague County, Texas $\quad 1350 \pm 150$

Charcoal from base of terrace on $\mathrm{N}$ bank of Dye Creek, $6 \mathrm{mi} \mathrm{S}$ of St. Joseph $\left(33^{\circ} 35^{\prime} \mathrm{N}\right.$ Lat, $97^{\circ} 30^{\prime} \mathrm{W}$ Long $)$, Montague County, Texas. Found 
with vertebrates, invertebrates and flint chips. Should help to interpret the terrace development and history of stream entrenchment. Coll. April 1958 by W. W. Dalquest, William Melton and C. W. Hibbard; subm. by Hibbard, Univ. of Michigan.

\section{B. Colorado}

Colorado lake-bed samples, dated in order to correlate with microfossils, the rate of sediment deposition, trophic changes in lake waters, vegetational history of areas immediately surrounding the three sites, and possibly with the last recession of valley glaciers of the Colorado Front Range. A comprehensive paper including these phases of the project is now in preparation at Univ. of Colorado. All samples were coll. and subm. by R. W. Pennak, Univ. of Colorado, Boulder.

\section{Muskee Lake series, Colorado}

Organic lake sediment from freshly exposed side of large test pit, dug in artificially drained lake, could be taken easily with no danger of contamination. Muskee Lake is a small lake with intermittent outflow, $2617 \mathrm{~m}$ alt $\left(39^{\circ}\right.$ $59^{\prime} \mathrm{N}$ Lat, $105^{\circ} 30^{\prime} \mathrm{W}$ Long), Boulder County, Colorado. Coll. November 1954. Comment: deposits below these samples are sand, gravel and clay mixtures.

M-948. $60 \mathrm{~cm}$ depth

$$
\begin{array}{r}
920 \pm 150 \\
3120 \pm 200 \\
3870 \pm 250 \\
4350 \pm 400
\end{array}
$$$$
\text { M-950. } 40 \text { to } 46 \mathrm{~cm} \text { depth }
$$$$
\text { M-951. } 60 \text { to } 66 \mathrm{~cm} \text { depth }
$$$$
\text { M-952. } 80 \text { to } 86 \mathrm{~cm} \text { depth }
$$

\section{Silver Lake Gate bog series, Colorado}

Lake sediments from a filled-in pond formerly supplied with water from a stream now $40 \mathrm{~m}$ from edge of bog proper, alt $2980 \mathrm{~m},\left(40^{\circ} \mathrm{l}^{\prime} \mathrm{N}\right.$ Lat, $105^{\circ}$ 35' W Long), Boulder County, Colorado. The bog vegetation is sedge and arctic willow. Samples taken September 1955 with Hiller peat borer. Comment: sampler could not be forced to a greater depth because of coarse gravel.

$$
\begin{array}{llr}
\text { M-953. } & \text { From surface to depth of } 25 \mathrm{~cm} & <150 \\
\text { M-954. } & \text { Between depths of } 50 \text { to } 75 \mathrm{~cm} & 910 \pm 150 \\
\text { M-955. } & \text { Between depths of } 100 \text { to } 125 \mathrm{~cm} & 3470 \pm 250 \\
\text { M-956. } & \text { Between depths of } 150 \text { and } 175 \mathrm{~cm} & 6190 \pm 300
\end{array}
$$

\section{Bedrock Lake series, Colorado}

A small lake with intermittent outflow at alt of $3090 \mathrm{~m},\left(40^{\circ} 6^{\prime} \mathrm{N}\right.$ Lat, $105^{\circ} 33^{\prime} \mathrm{W}$ Long), Boulder County, Colorado. Organic lake deposits coll. October 1953 with a Hiller peat borer. Lake was $1.6 \mathrm{~m}$ deep at sampling point in center of basin.

M-957. Between mud-water interface and a depth of $10 \mathrm{~cm}$ 
M-958. Sediment 20 to $30 \mathrm{~cm}$ below mud-water interface

$1525 \pm 200$

M-959. Sediment 40 to $50 \mathrm{~cm}$ below mud-water interface $2600 \pm 200$

M-960. Sediment 60 to $70 \mathrm{~cm}$ below mud-water interface $460 \pm 200$

M-961. Sediment 80 to $90 \mathrm{~cm}$ below mud-water interface $3330 \pm 200$

\section{M-962. Sediment 100 to $110 \mathrm{~cm}$ below mud-water interface} $2890 \pm 200$

M-963. Sediment 120 to $130 \mathrm{~cm}$ below mud-water interface $3020 \pm 200$

M-964. Sediment 140 to $150 \mathrm{~cm}$ below mud-water interface $5940 \pm 700$

M-965. Sediment 160 to $170 \mathrm{~cm}$ below mud-water interface $5560 \pm 300$

M-966. Sediment 180 to $190 \mathrm{~cm}$ below mud-water interface $6680 \pm 400$

\section{M-939. American Falls Lake Beds, Idaho}

$>\mathbf{3 0 , 0 0 0}$

Charcoal from the American Falls Lake beds on SE shore of American Falls Resevoir ( $42^{\circ} 56^{\prime} \mathrm{N}$ Lat, $112^{\circ} 41^{\prime} \mathbb{W}$ Long), Bingham County, Idaho. Charcoal scattered through fossiliferous zone, upper limits lying ca. 14 in. below present beach surface, lower limits from 2 to $3 \mathrm{ft}$ below beach surface. The zone is composed of sand, locally cemented by limonite. Site is ca. $10 \mathrm{yd}$ out from cliff behind beach and $30 \mathrm{ft}$ above nearby Bison latifrons horizons, dated W-358, at $>32,000$ (USGS IV). There is no reason to suppose the charcoal was left by man. Coll. August 1959 and subm. by M. L. Hopkins, Idaho State College, Pocatello. See Hopkins $(1951 ; 1955)$ for report on fauna of this deposit.

M-1052. Clark Peninsula, Windmill Island, Antaretica $6040 \pm \mathbf{2 5 0}$

Coralline algae Archaeolithothamnion from Clark Peninsula, Windmill Island ( $66^{\circ} 15.5^{\prime} \mathrm{S}$ Lat, $110^{\circ} 31.2^{\prime} \mathrm{E}$ Long), Antarctica. Sample found $65 \mathrm{ft}$ above present sealevel. Coll. by R. L. Cameron, Columbus, Ohio; subm. by J. H. Zumberge, Univ. of Michigan. Comment: raised beaches, indicating higher relative sealevel, exist up to $100 \mathrm{ft}$ on Windmill Islands and are believed to have been formed during recent geologic period. The age of the algae should approximate the climax of the warming trend following the retreat of the Wisconsin-Würm ice.

\section{ARCHAEOLOGIC SAMPLES}

\section{A. Upper Mississippi Valley and Great Lakes}

M-790. Missaukee Mound 2, Michigan

$750 \pm 150$

Bark from a layer 15 in long by 10 in. wide and 1.5 in. thick, over a copper axe (6.25 in. by $1.5 \mathrm{in}$. at the poll end, $2.5 \mathrm{in}$. at the bit end, and 
0.375 in. thick). Axe had been inclosed in beaver(?) skin and tied, near bit end, with a 2-ply, 2-twisted, (counter clockwise) cord of bast fiber. Axe was associated with an adult-male burial in a small, low mound $\left(44^{\circ} 17^{\prime} \mathrm{N}\right.$ Lat, 85 ${ }^{\circ} \mathrm{W}$ Long) sec. 23, Aetna Township, Missaukee County, Michigan. Comment: excavated 1925 by E. F. Greenman (Greenman, 1926) and originally attributed to the Hopewell culture. Association of the mound with the Missaukee earthworks, burial characteristics, and the $\mathrm{C}^{14}$ date, A.D. 1270 , indicates Late Woodland age.

M-1070. Dumaw Creek Site, Michigan $280 \pm 150$

Organic material with burial at Dumaw Creek $\left(43^{\circ} 50^{\prime} \mathrm{N}\right.$ Lat, $86^{\circ} 20^{\prime}$ W Long), sec. 5, R17W, T16N, Oceana County, Michigan. Coll. 1917 by Carl Schrumpf. Organic material composed of witches' brew of fur and hair from raccoon, beaver, elk, bear and buffalo, plus human hair and fragments of human and animal tissue, in direct association with skull of burial found beneath roots of white pine stump (Pinus strobus) 30 in. in diam. Tree probably was cut between A.D. 1870 and 1880. Cultural remains from this site are indicative of the very Late Woodland period. There is, however, no evidence of European contact. Copper artifacts are of Lake Superior copper. Subm. by G. I. Quimby, Chicago Natural History Museum, who is preparing a publication on the burial.

\section{Juntunen Site series, Michigan}

Charcoal from the Juntunen Site (20 MK 1), (45 $49^{\prime} \mathrm{N}$ Lat, $84^{\circ} 35^{\prime} \mathrm{W}$ Long), Mackinac County, Michigan. Series should date time span of occupation of this Late Woodland site, as well as dating three separate occupations separated by wind-blown sand. Coll. August 1960 by A. T. Steegman, Univ. of Michigan; subm. by Alan McPherron for the Museum of Anthropology, Univ. of Michigan.

M-1140. Juntunen Site, $1.5 \mathrm{ft}$

$890 \pm 150$

Sample from square 1880-1130 between square sheets 4 and 5 at a depth of $1.5 \mathrm{ft}$.

M-1141. Juntunen Site, $2.0 \mathrm{ft} \quad 1050 \pm 150$

Sample from square 1880-1130 between square sheets 6 and 7 at a depth of $2.0 \mathrm{ft}$. This level is a grey-black layer, separated by sand from the level above and below.

M-1142. Juntunen Site, $4.0 \mathrm{ft}$

$1125 \pm 150$

Sample from square $1880-1130$ between square sheets 10 and 11 at a depth of $4.0 \mathrm{ft}$. This is the lowest gray band containing cultural material. This layer is separated from the overlying zones by wind-blown sand.

\section{M-907. Turpin Farm Site, Ohio $\quad 675 \pm 150$}

Charcoal pieces from a single $\log$ found at Turpin Farm Site, $100 \mathrm{yd} \mathrm{W}$ of the Turpin house (ca. $39^{\circ} 15^{\prime} \mathrm{N}$ Lat, 84 $4^{\circ} 5^{\prime} \mathrm{W}$ Long), Anderson Township, Hamilton County, Ohio, from bottom of a refuse pit which extends from 2 to $3 \mathrm{ft}$ below the surface. Coll. December 1958 by J. H. Chapman, Cincinnati, 
Ohio; subm. by J. B. Griffin. Fort Ancient pottery of the Madisonville Focus variety was found beside and underneath the wood. Comment: date seems satisfactory for a part of the time span of the Fort Ancient Aspect (Griffin, 1943; Oehler, 1950).

M-910. Haffner-Kuntz Site, Ohio

$1375 \pm 150$

Charcoal from Haffner-Kuntz Site (33 Ha 9), NE of Kellogg Avenue Bridge over Little Miami River (ca. $39^{\circ} 15^{\prime} \mathrm{N}$ Lat, $84^{\circ} 26^{\prime} \mathrm{W}$ Long), Anderson County, Ohio. Charcoal was found with shell and bone at $3 \mathrm{ft}, 6$ in. to 4 ft depth. Coll. 1958 by W. F. Starr, Cincinnati Museum of Natural History; subm. by J. B. Griffin. In this Fort Ancient site 540 shell-tempered sherds were found (Starr, 1960). Over three-fifths of the sherds are Madisonville Plain, the remainder being equally divided between cord-marked and smoothed-over cord-marked. One of the vessels was a long-necked water bottle. Two extended burials were also found, one with slab-lined tomb and a triangular projectile point. Comment: date is slightly greater than expected.

M-928. West Mound, Ohio $1830 \pm 200$

Charcoal from $\mathrm{N}$ side of tomb 4 in a Hopewell mound $\mathrm{N}$ of Marshall and near Rocky Fork Lake (ca. $39^{\circ} 11^{\prime} \mathrm{N}$ Lat, $83^{\circ} 29^{\prime} \mathrm{W}$ Long), Highland County, Ohio. This is the same mound dated as M-650, $1890 \pm 200$ (Michigan, III). This mound was excavated and a report published by Tom Porter and Don McBeth $(1956 ; 1957)$; subm. by Don McBeth, Kingston, Ohio.

M-929. Clough Mound, Ohio $\quad 2120 \pm 200$

Charcoal from burned house in Adena mound on $\mathrm{N}$ border of Waverly, Peepee Township (ca. $39^{\circ} 9^{\prime} \mathrm{N}$ Lat, $82^{\circ} 58^{\prime} \mathrm{W}$ Long), Pike County, Ohio. Mound partially excavated in the 1890 s by Gerard Fowke $(1902 ; 1928)$. It is listed as mound 17 by Greenman (1932) and as mound 192 by Webb and Baby (1957). Excavated in 1953 by McBeth and Porter who reported their observation in Porter and McBeth (1956) ; subm. by Don McBeth, Kingston, Ohio.

M-871. Beloit Mound Group, Rock County, Wisconsin $1460 \pm 150$

Charcoal from mound 6 on Beloit College campus ( $42^{\circ} 31^{\prime} \mathrm{N}$ Lat, $89^{\circ} 1^{\prime}$

W Long), Rock County, Wisconsin. Samples lay on floor of mound. Original humus layer had been removed before erection of the mound. This and other mounds are regarded as part of the Effigy Mound culture of Wisconsin. Date is apparently early in the life of the Effigy Mounds of the upper Mississippi Valley. Excavated 1958 and subm. by Tyler Bastian, Univ. of Utah.

\section{Steuben Site series, Illinois}

Mussel shell and charcoal from a Hopewell burial mound and a related village occupation at Steuben Site $\left(40^{\circ} 59^{\prime} \mathrm{N}\right.$ Lat, $89^{\circ} 26^{\prime} \mathrm{W}$ Long) Marshall County, Illinois. A report on this site will be published by Museum of Anthropology, Univ. of Michigan.

M-439. Steuben Site, Mound $\mathrm{Ma}^{\circ} 202$

$2110 \pm 200$

Mussel shell from mound containing Late Hopewell Zoned pottery and 
other artifacts. Excavated in early 1950s by D. F. Morse and D. F. Morse, Jr., of Peoria. This date is probably somewhat too early, as mussel shell from the Illinois River tends to yield dates substantially earlier than true age. See also M-378, $1650 \pm 350$ (Michigan II) charred wood from the same site.

M-440. Steuben Village, level 4

$1325 \pm 200$

Charcoal from level 4 of strata pit excavated by D. F. Morse. Pottery sequence in this pit runs from Hopewell to early Late Woodland types.

M-441. Steuben Village, level 5

$1275 \pm 200$

Charcoal sample from level 5 of strata pit excavated by D. F. Morse. Pottery sequence in this pit runs from Hopewell to early Late Woodland.

M-545. Steuben Village, unit \#2, 1.5 to $2 \mathrm{ft} \quad 1900 \pm 200$

Charcoal sample from excavation unit \#2, 1.5 to $2 \mathrm{ft}$ in strata pit excavated by J. B. Griffin and D. F. Morse for Museum of Anthropology, Univ. of Michigan.

M-548. Steuben Village, unit \#2, 2 to $2.5 \mathrm{ft} \quad 2010 \pm 200$

Charcoal sample from 2 to 2.5 -ft level of pit excavated by J. B. Griffin and D. F. Morse, Univ. of Michigan.

M-758. MeDougal-Hartman Mound, Illinois

$2270 \pm 200$

Wood fragments from undisturbed $\log$ from the McDougal-Hartman Mound, located $0.25 \mathrm{mi} \mathrm{S}$ of the Dickinson site, $\mathrm{N}$ of Mossville $\left(40^{\circ} 50^{\prime} \mathrm{N}\right.$ Lat, $89^{\circ} 31^{\prime} 30^{\prime \prime} \mathrm{W}$ Long), Peoria County, Illinois. Mound was disturbed by amateurs in 1941. A central sub-floor $\log$ tomb and bundle burials at either end were undisturbed. A vessel of Havana Zoned Stamped cord-wrapped stick variety was associated with burials at $\mathrm{W}$ side of tomb. Sample coll. September 1957 by Elaine Bluhm and W. J. Beeson (Bluhm and Beeson, 1960); subm. by J. C. McGregor, Univ. of Illinois, Urbana.

M-759. Renchville Mound, Illinois

$1990 \pm 200$

Wood fragments from logs placed over burials in the Renchville Hopewell Mound ( $40^{\circ} 50^{\prime} \mathrm{N}$ Lat, $89^{\circ} 31^{\prime} 30^{\prime \prime} \mathrm{W}$ Long), Peoria County, Illinois. Associated with burials and a cache of bone awls, copper awl, flake knives, bear teeth and a wolf incisor. Coll. by Elaine Bluhm and W. J. Beeson (Bluhm and Beeson, 1960) ; subm. by J. C. McGregor, Univ. of Illinois, Urbana.

\section{M-760. Caterpillar Mound, Illinois}

$2010 \pm 150$

Wood from Caterpillar Mound, $\mathrm{N}$ of Mossville $\left(40^{\circ} 50^{\prime} \mathrm{N}\right.$ Lat, $89^{\circ} 31^{\prime}$ $30^{\prime \prime}$ W Long), Peoria County, Illinois. Sample is from well-preserved log at N edge of Hopewell tomb, on top of bundle burials. Rectangular sub-floor tomb, dug into gravel, contained extended burials in center and bundle burials at $\mathrm{N}$ end. Copper wire wound spirally around a wooden staff, a flake knife, and a curved-base platform pipe were associated with burials. Coll. September 1957 by Elaine Bluhm and W. J. Beeson (Bluhm and Beeson, 1960); subm. by J. C. McGregor, Univ. of Illinois, Urbana. A sample of the same log was run at Univ. of Arizona as A-60A with a date of $1900 \pm 350$ and as A-80B with a date of $2080 \pm 200$ ('Arizona II). 
M-743. Harper's Ferry Mound group, Iowa

$1730 \pm 150$

Wood charcoal from Valley Mound in Harper's Ferry Mound group $\left(42^{\circ}\right.$ $11^{\prime} \mathrm{N}$ Lat, $91^{\circ} 10^{\prime} \mathrm{W}$ Long). The mound contained evidence of heavy firing in a shallow pit. No burials were found but very late rocker-stamped pottery and a Late Woodland vessel with cord-impressed, upper-rim design were recovered. Excavated in 1934. Collections of State Historical Society of Iowa; subm. by W. C. Logan, National Park Service, Washington, D. C.

M-744. French Town Mound group, Iowa

$1720 \pm 150$

Wood charcoal from mound of above group, located in Clayton County, Iowa $\left(42^{\circ} 49^{\prime} \mathrm{N}\right.$ Lat, $91^{\circ} 8^{\prime} \mathrm{W}$ Long). A charcoal stratum, $12 \mathrm{ft}$ in diam. was found in a burial pit in this mound. Below charcoal layer was a small very late Hopewell vessel with plain rocker-stamping on the body. Material in collections of State Historical Society of Iowa; subm. by W. C. Logan, National Park Service, Washington, D. C.

\section{Turin Site series, Iowa}

Human and bison bones from Turin Site $\left(42^{\circ} 1^{\prime} 24^{\prime \prime} \mathrm{N}\right.$ Lat, $95^{\circ} 57^{\prime} 55^{\prime \prime}$ W Long), Monona County, Iowa.

M-932. Turin Site, 13- to 14-ft level

$4720 \pm 250$

Most of skeleton no. 3, an adolescent found flexed on its left side, in burial pit sprinkled with red ochre and associated with a side-notched projectile point and a string of several gastropod shell beads. This and other pits were dug in sandy to silty loess. Coll. September 1955 by R. J. Ruppé and W. D. Frankforter; subm. by Ruppé, State Univ. of Iowa (Ruppé, 1956).

M-1071. Turin Site, 11 -f t, 8 in.-level

$6080 \pm 300$

Lumbar vertebrae and sacrum from Bison sp. found in articulated position, lying horizontally in $\mathrm{N}$ face of excavation in loess valley fill which contained human skeleton (M-930, this date list). Bison bones were $30 \mathrm{ft} \mathrm{SE}$ in an horizon $8 \mathrm{ft}$ below the human remains $(11 \mathrm{ft}, 8 \mathrm{in}$. below the surface, according to Frankforter). Stratification of site was continuous across this face. Bones coll. August 1955 and subm. by W. D. Frankforter, Sanford Museum, Cherokee, Iowa (Frankforter and Agogino, 1959). Comment: these dates offer an index of the rate of loess accumulation along E side of Mississippi River. Simonsen Site, which contained point of a type similar to the single point found with M-930, was dated $8430 \pm 520$ by Isotopes, Inc. (I(UW) -79, Isotopes I). The Simonsen Site also contains bison (Bison occidentalis).

\section{B. Lower Mississippi Valley and Southeast}

\section{M-909. Gaines Site, Kentucky}

$\mathbf{2 0 7 0} \pm \mathbf{2 0 0}$

Charcoal from Gaines Mound ( $39^{\circ} 8^{\prime} \mathrm{N}$ Lat, 84. $44^{\prime} \mathrm{W}$ Long), Boone County, Kentucky. Sample is from top level, 5 to $6 \mathrm{ft}$ above mound base. Cultural material is judged to be Late Adena. Coll. 1958 by Ellis Crawford, William H. Behringer Foundation; subm. by J. B. Griffin, Univ. of Michigan. Sample M-908, $1975 \pm 200$ (Michigan V) came from base of mound. Comment: it is doubtful that Late Adena can be as late as some archaeologists have accepted. 
Charred pieces of bone from Vaughn Site I, $23 \mathrm{SN} 203$, (36 $36^{\circ}$ N Lat, $93^{\circ} 19^{\prime} \mathrm{W}$ Long), Stone County, Missouri. Sample from deep combinationcremation-and-bundle burial at a depth of 4 to $6 \mathrm{ft}$ below surface of terrace of White River. Specimen was associated with an engraved bowl and a gorget. Vessel appears to be from the Caddoan area and resembles middle-to-late Spiro types. Coll. July 1955 and subm. by C. H. Chapman, Univ. of Missouri, Columbia, who has given a preliminary report on this site (Chapman, 1957).

M-897. Creve Coeur Lake, Missouri

$\mathbf{2 0 7 0} \pm \mathbf{2 0 0}$

Charred antler (originally B 277) from a bluff above Creve Coeur Lake Site (23 SL 20), Creve Coeur Lake (ca. $38^{\circ} 40^{\prime} \mathrm{N}$ Lat, $90^{\circ} 30^{\prime} \mathrm{W}$ Long), St. Louis County, Missouri. Sample from level XI, 34 to 37 in. below datum, associated with Middle and Late Hopewell sherds and worked stone. Coll. and subm. by L. W. Blake, St. Louis, Missouri.

M-918. Cherry Valley Site, Arkansas

$1030 \pm 150$

Charred bone from burial 86 at summit of primary mound 3 ( $11 \mathrm{~N} \mathrm{17)}$ in the Cherry Valley Mound group ( $35^{\circ} 26^{\prime} \mathrm{N}$ Lat, $90^{\circ} 45^{\prime} \mathrm{W}$ Long), Mitchell Township, Cross County, Arkansas. Found in association with seeds and cloth material. Coll. 1958 and subm. by Gregory Perino, Thomas Gilcrease Foundation, Tulsa, Oklahoma. Comment: M-917 (Michigan V, p. 37) from beneath mound 2 was dated $1250 \pm 150$. This site yielded a new culture complex for $\mathrm{NE}$ Arkansas and is important because of a remarkable resemblance of some of the pottery vessels to the Tippett bean pot, found at Cahokia, in Illinois. May represent splinter group created by population increase at Cahokia.

\section{M-729. Bowman Farm Site, Tennessee}

$760 \pm 150$

Charred cane, thatch, and wood from Bowman Farm Site, mound $2\left(36^{\circ}\right.$ $19^{\prime} 30^{\prime \prime} \mathrm{N}$ Lat, 84. $1^{\prime} 45^{\prime \prime} \mathrm{W}$ Long), Campbell County, Tennessee. From collapsed, burned arbor of small poles, earlier than mound 1 and disturbed by building on primary floor of mound 1. Coll. February 1934 and subm. by T. M. N. Lewis, Univ. of Tennessee, Knoxville. Should date Irvin Focus in Norris Basin area (see Webb, 1938, p. 10-25, for discussion of this site), and is probably slightly later than Hiwassee Island Focus.

M-730. Alford Site, Tennessee

$930 \pm 150$

Charred wood from the Alford Site, mound $4\left(35^{\circ} 50^{\prime} 10^{\prime \prime} \mathrm{N}\right.$ Lat, $84^{\circ}$ $33^{\prime}$ W Long), Roane County, Tennessee. Specimen was from burned log associated with burial $6 \mathrm{ft}, 7$ in. below apex of mound. Coll. April 194.1 by Wendell Walker; subm. by T. M. N. Lewis, Univ. of Tennessee, Knoxville. Should date the late Hamilton burial-mound culture. Pottery found at site is predominately Hamilton Plain (Lewis and Kneberg, 1946, p. 83).

M-731. De Armond Site, Tennessee

$670 \pm 150$

Charcoal from burned roof of Early Mississippi council house (distinguished by small posts) at de Armond Site, $\left(35^{\circ} 51^{\prime} 10^{\prime \prime} \mathrm{N}\right.$ Lat, $84^{\circ} 35^{\prime} 5^{\prime \prime} \mathrm{W}$ Long), Roane County, Tennessee. The house was first structure built on old humus beneath platform mound. Coll. May 1941 by John Alden; subm. by T. 
M. N. Lewis, Univ. of Tennessee, Knoxville. Comment: sample should date a late variant of Hiwassee Island Red-on-Buff pottery. A wide-neck bottle with rayed-sun design lay on floor of structure. Sherds of earlier Red-on-Buff variant were present on the site.

\section{Russell Cave series, Alabama}

Charcoal from within Russell Cave ( $34^{\circ} 58^{\prime} \mathrm{N}$ Lat, $85^{\circ} 48^{\prime} 32^{\prime \prime}$ W Long), Doran Cove, Jackson County, Alabama. The cave, as described by Broyles (1958) and Miller (1958), has been excavated extensively. The excavation controls used by Miller are not the same as those of the earlier excavators. Coll. and subm. by C. F. Miller, Smithsonian Institution, Washington, D. C.

M-845. Russell Cave, 2.0 ft.

$8750 \pm 500$

Charcoal from hearth in square 10 , at depth of $2.0 \mathrm{ft}$. Sample associated with Middle Woodland cultural material. Comment: two dates attributed to this complex have been reported previously; M-557 (Michigan IV, p. 187) from the Middle Woodland level within the cave dated $1110 \pm 200$ years ago; M.765 (Michigan IV, p. 187), a Middle Woodland sample from a mound 100 yd. NNE of cave gave a date of $1560 \pm 200$. M-845 is much too early to be attributed to any Woodland culture.

\section{M-846. Russell Cave, 7.5 ft.}

$7970 \pm 450$

Charcoal from large shallow fire pit in square 12 at depth of $7.5 \mathrm{ft}$. Sample is attributed by the excavator to an Early Archaic context. Comment: M-59l (Michigan II, p. 1101) from the 5.5-ft level, attributed by the excavator to the Archaic, was dated $6300 \pm 350$.

\section{M-847. Russell Cave, 8.5 ft.}

$8350 \pm 500$

Charcoal blanket covering a typical Early Archaic semiflexed male burial in square 30 at a depth of $8.8 \mathrm{ft}$. Comment: M.766 (Michigan IV, p. 187) from earliest occupation level at a depth of $23 \mathrm{ft}$ was dated at $9020 \pm 300$. An adequate correlation of the dates with the cultural complexes and depth from datum will be provided in Miller's publication of his excavations.

\section{M-995. Money's Bend Site, Alabama $\quad \mathbf{5 5 0} \pm 150$}

Charcoal from village site midway between the Coosa and Chatooga rivers, ca. $2.5 \mathrm{mi} \mathrm{SW}$ of Cedar Bluff (ca. $34^{\circ} 12^{\prime} \mathrm{N}$ Lat, $85^{\circ} 38^{\prime} \mathrm{W}$ Long), Cherokee County, Alabama, from borrow trench of feature 1, a palisade. Site was interpreted as late Middle Woodland because of high proportion of plain limestone-tempered pottery. Excavated summer of 1959 and subm. by C. H. Fairbanks, Florida State Univ., Tallahassee (Keel, 1960). Comment: date seems to be too young but the charcoal may well be intrusive and associated with Mississippi pottery on the site.

\section{M-1064. Etowah Site, Georgia}

$850 \pm 150$

Charcoal from Etowah Site ( $34^{\circ} 5^{\prime} \mathrm{N}$ Lat, $84^{\circ} 50^{\prime} \mathrm{W}$ Long), $3 \mathrm{mi} \mathrm{S}$ of Cartersville, Bartow County, Georgia. Sample (cat. \#3459) from feature 19 of mound C. Coll. September 1958 and subm. by L. H. Larson, Atlanta, Georgia. Comment: this famous center of Mississippi culture is particularly 
important for establishing the duration of the climax of southeastern ceremonial activities (Kelly and Larson, 1957). Other samples from mound $C$ have been dated $725 \pm 200,910 \pm 200$ and $500 \pm 250$ (M-402, M-542 and M-543, Michigan IV, p. 188). Archaeologic data also indicate that burial activities at mound $\mathrm{C}$ extended a considerable period of time.

\section{Chauga Mound series, South Carolina}

Charcoal from Chauga Mounds, Hartwell Basin Survey (34 $36^{\prime \prime}$ N Lat, $83^{\circ} 10^{\prime} 02^{\prime \prime}$ W Long), Oconee County, South Carolina. Coll. 1958 by R. S. Neitzel; subm. by A. R. Kelly, Univ. of Georgia, Athens.

\section{M-933. Chauga Mound, Feature 15}

$1120 \pm 150$

Charcoal from N50-60, W60-70; Fd. no. 191 in feature 15, a hearth overlying burial 17. The burial was intrusive from the mound 3 phase into feature 14, of the mound 1 phase. Comment: according to Kelly, mound 3 and 4 stages at Chauga represent a composite Etowah-Savannah culture, and are approximately equivalent to Etowah 3 at the Etowah (type) site.

M-934. Chauga Mound, Feature 26

$1070 \pm 150$

From N60-70, W70-80, Fd. 178, feature 26, the pre-mound base. Comment: should be older than M-933 and M-935.

\section{M-935. Chauga Mound, Feature 9}

From N90-100, W70-80, Fd. 143, feature 9, adjacent to Fd. 144 (rock slab) on mound 3. Belongs with M-933 to about the mound 3 stage of Chauga mound.

\section{Northeastern United States and Canada}

\section{Cresap Mound series, West Virginia}

Charcoal from the Cresap Mound Site ( $39^{\circ} 50^{\prime} \mathrm{N}$ Lat, $80^{\circ} 49^{\prime} \mathrm{W}$ Long), Marshall County, West Virginia. Coll. summer 1958 and subm. by D. W. Dragoo, Carnegie Museum, Pittsburgh, Pennsylvania. The series dates an Eastern Adena mound, exceptional in that good artifact types can be correlated with the dates. Dragoo has made preliminary reports on the site $(1958 ; 1959 \mathrm{a}$; $1959 b$ ).

\section{M-976. Cresap Mound, below floor}

$2240 \pm 150$

Charcoal (originally F. C. \#3191) found in fill in sub-floor tomb (feature 28, burial 54). A fire had been built over the tomb, and with collapse of the $\operatorname{logs}$ the charcoal fell directly into the tomb. Sample was found $7.5 \mathrm{ft} E$ and $210 \mathrm{ft} S$ at depth of 0 to $0.8 \mathrm{ft}$ below floor of mound.

M-975. Cresap Mound, $0.8 \mathrm{ft}$ above floor

$$
2190 \pm 200
$$

Charcoal (originally F. C. \#3187) from near edge of West Primary mound, $8 \mathrm{ft} W$ and $9.2 \mathrm{ft} \mathrm{N}$, at an elevation of $0.8 \mathrm{ft}$ above floor of mound. Samples M-975 and M-976 are from widely separate features near the floor of the mound, and should date an early period in the construction of the mound.

M-974. Cresap Mound, $6.7 \mathrm{ft}$ above floor $\quad \mathbf{2 0 2 0} \pm 150$

Charcoal (originally F. C. \#3185) from feature 24, burial 44, 13.1 to 
$16.1 \mathrm{ft} \mathrm{E}$ and 0 to $3.2 \mathrm{ft} \mathrm{N}$ at an elevation of $6.75 \mathrm{ft}$ above floor of mound. Sample came from a large feature, near several other features, on a major level of activity about midway in the mound; should date the middle occupation of the mound.

\section{Site 18 AN 18 series, Maryland}

Charcoal and bark from Site 18 AN 18, along Chesapeake Bay $\left(38^{\circ} 53^{\prime}\right.$ $\mathrm{N}$ Lat, $76^{\circ} 31^{\prime} \mathrm{W}$ Long). Site is a cremation and reburial cemetery of a culture with many similarities, especially in stone pipes, to Adena and Ohio artifacts (Ford, 1958).

M-927. Site 18 AN 18, crematory pit

$\mathbf{2 3 0 0} \pm \mathbf{2 0 0}$

Charcoal scattered throught crematory pit and concentrated in fire pits located within crematory pit; also, bark on top of reburial in separate pit. Coll. 1955 to 1957 and subm. by T. L. Ford, Jr., Archaeological Society of Maryland, Buxton.

M-419B. Site 18 AN 18, excavation $\# 7 \quad 1960 \pm 200$

Charcoal from excavation \#7, specimen 7B. Coll. and subm. by John Witthoft, Historical Commission, Harrisburg, Pennsylvania, and T. L. Ford, Jr.

M-420B. Site 18 AN 18, excavation $\# 8 \quad 2110 \pm 200$

Charcoal from excavation \#8, specimen 8B. Coll. and subm. by John Witthoft, Historical Commission, Harrisburg, Pennsylvania, and T. L. Ford. Comment: other dates from this same site are: M-419C, $1700 \pm 250$ (Michigan I) ; M-416A, 2310 \pm 200 ; M-417A, $1850 \pm 200$ (Michigan V).

\section{M-911. Lamoka Lake Site, New York $\quad 4480 \pm 300$}

Wood charcoal, mostly carbonized bark, from hearth 1 in test trench 2 , Lamoka Lake Site $\left(42^{\circ} 25^{\prime} \mathrm{N}\right.$ Lat, $77^{\circ} 5^{\prime} \mathrm{W}$ Long), Tyrone Township, Schuyler County, New York. The hearth was found at base of a narrow subsoil pit, 8 in. wide and 8 in. deep. Overlying soil consisted, from above downward, of a 9-in. plow zone, a 7-in. white and gray ash layer and 8 in. of dark soil with bone refuse. Coll. 1958 and subm. by W. A. Ritchie, New York State Museum and Science Service, Albany, New York. Comment: this is the type site of the Lamoka culture of the Early Archaic in New York State. Another type Lamoka sample is M-912, 4410 \pm 250 (Michigan V, p. 38); (see earlier summary in Michigan IV, p. 184).

\section{M-969. Wapanucket Site \#6, Massachusetts $\quad 4300 \pm 250$}

Charcoal from burial no. 2 and 3 of Wapanucket Site \#6, N shore of Lake Assawompsett (41 $1^{\circ} 51^{\prime} 18^{\prime \prime} \mathrm{N}$ Lat, $71^{\circ} 54^{\prime} 10^{\prime \prime} \mathrm{W}$ Long), Plymouth County, Massachusetts. Burials were found at ca. $40 \mathrm{~cm}$ below present surface and extended to $85 \mathrm{~cm}$ below the present surface. Cremated human bone was present. Burial no. 2 contained a quantity of red ochre, four gouges, one plummet and two sharpening stones; burial no. 3 contained a semi-lunar knife and a sharpening stone. Coll. 1957 by A. C. Staples and Maurice Robbins; subm. by Robbins, Attleboro, Massachusetts. Comment: date confirms suspicion that this crematory pit and pit \#29 near lodge floor \#5 (M-764, 4250 \pm 300 , Michigan IV, p. 184) are from the same general period (Robbins, 1960). 


\section{Western United States}

M-946. The Pinnacles Site, South Dakota

$1060 \pm 150$

Fragments of bone and charcoal from The Pinnacles site, Badlands National Monument $\left(43^{\circ} 52^{\prime} \mathrm{N}\right.$ Lat, $102^{\circ} 13^{\prime} \mathrm{W}$ Long), South Dakota. Sample was from the lowest of four occupation levels in the side of a gully and from 13 to $14 \mathrm{ft}$ beneath the surface. Associated pottery was identified as Stanley Braced Ware. Coll. 1958 and subm. by D. C. Taylor, Montana State Univ., for the U. S. National Park Service. Comment: this date does not support a geologic interpretation of the overburden as having been deposited during Altithermal time.

\section{M-947. Conata Basin Site, South Dakota}

$660 \pm 150$

Bison bone from Conata Basin site, Dillon Pass area (ca. $43^{\circ} 45^{\prime} \mathrm{N}$ Lat, $102^{\circ} 06^{\prime}$ W Long), Badlands National Monument, South Dakota. The bison bones were in a clay deposit, 3 to $3.5 \mathrm{ft}$ below ground surface. The clay deposit was overlain by alluvial fill. Coll. June 1958, by John Clark, South Dakota School of Mines; subm. by D. C. Taylor, Montana State Univ., Missoula, for U. S. National Park Service. Comment: this date does not support an interpretation that the bison was Late Pleistocene or early recent in age.

\section{Glendo Reservoir Site series, Wyoming}

Wood samples from the Glendo Reservoir Site (48 Pl 24), Glendo Reservoir area, near town of Glendo (ca. $42^{\circ} 30^{\prime} \mathrm{N}$ Lat, $105^{\circ} 1^{\prime}$ WLong), Platte County, Wyoming. Coll. and subm. by William Mulloy, Univ. of Wyoming, Laramie.

\section{M-971. Glendo Resevoir Site, habitation \#6, upper level}

Charred wood (originally \#2) from upper level of habitation \#6, associated with Late Middle period artifact complex. Mulloy estimated date ca. 3000 B.P. Comment: sample originally contained many rootlets.

M-972. Glendo Resevoir Site, hearth $\quad 2020 \pm \mathbf{2 0 0}$

Wood (originally \#3) from hearth 441 in same stratified area as M-971 but at a lower level, associated with Middle Period complex, expected to date near M-971.

\section{M-973. Glendo Resevoir Site, above habitation \#6}

Wood (originally \#4) from a level stratigraphically above Late Middle Period occupation. Sample was associated with a somewhat scanty Late Period complex. Estimated age, A.D. 500, or later.

\section{M-783. Thorne Cave Site, Jensen, Utah}

$4230 \pm 250$

Charcoal from remains of a campfire found in lowest habitation layer in Thorne Cave, on Cliff Creek $\left(40^{\circ} 30^{\prime} \mathrm{N}\right.$ Lat, $109^{\circ} 15^{\prime} \mathrm{W}$ Long), Uintah County, Utah. Cave is $100 \mathrm{ft}$ wide and $40 \mathrm{ft}$ deep. Deposits showing human habitation are ca. $6 \mathrm{ft}$ deep, overlain by 3 to $4 \mathrm{ft}$ of sterile sand. Coll. November 1957 and subm. by R. C. Thorne, Jensen, Utah. Comment: charcoal dates 
a non-ceramic complex, consisting of a notched scapula and a few flint pieces comparable to Danger Cave III (Jennings, 1957). Site is entirely sealed by alluvium, presumably of Altithermal age. Notched scapula is almost identical with one from Humboldt Cave, described by Heizer and Krieger (1956, p. 139). Age of material exceeds that of Humboldt Cave, but is slightly younger than expected by Jennings.

M-919. Stockhoff Ranch Site, Oregon

$2600 \pm 200$

Wood charcoal from test square $197+96.8$, level 5, Pacific Northwest Pipeline Archaeological Project, schedule 12, Stockhoff Ranch Site $\left(45^{\circ} 13^{\prime}\right.$ $\mathrm{N}$ Lat, $118^{\circ} \mathrm{l}^{\prime} \mathrm{W}$ Long), Union County, Oregon. This level is composed of water-laid materials ranging from pea-sized gravel to fine sand. Sample was associated with chipping detritus occurring from the surface to a depth of 3.5 ft. Coll. 1955 by A. L. Bryan and D. R. Touhy; subm. by E. H. Swanson, Idaho State College Museum, Pocatello. Comment: site a basalt quarry and contained tools very similar to those found by Carter (1958) in Reno area of Nevada. Carter claimed that his implements date from Wisconsin I to Wisconsin II, 30,000 to 10,000 B.P.

\section{M-942. Windy Spring Site, Washington}

$1080 \pm 200$

Turtle carapace from square 1211,24 - to 30 -in. level, and bone fragments from square IV, 36- to 42-in. level. Samples are from levels 5 thru 7 , the oldest culture-bearing strata, in yellow-gray part of "B" soil horizon at the Windy Spring Site (47 $21^{\prime}$ N Lat, $119^{\circ} 38^{\prime} \mathrm{W}$ Long), Grant County, Washington. Coll. August 1958 by B. R. Butler (1958); subm. by Douglas Osborne, Mesa Verde National Park, Colorado. Comment: the association is with polyhedral cores and microblades suggestive of northern influences and also with elements of plateau or desert culture, such as grinding slabs and manos.

\section{M-937. Childers Site, California}

$610 \pm 150$

Charcoal from the 12- to 24-in. level in an unstratified midden found at Childers Site $\left(39^{\circ} 22^{\prime} \mathrm{N}\right.$ Lat, $121^{\circ} 3^{\prime} 20^{\prime \prime} \mathrm{W}$ Long), Nevada County, California. The midden has a total depth of ca. 36 in. The site is a manifestation of the "Martis complex" as described by Heizer and Elsasser (1953). Coll. July 1954 and subm. by R. F. Heizer, Univ. of California.

M-938. Gunther Island Shellmound Site, California $1050 \pm 200$

Marsh material (carbonized wood and vegetable detritis material mixed with dirt) from the Gunther Island Shellmound Site $\left(40^{\circ} 48^{\prime} \mathrm{N}\right.$ Lat, $124^{\circ} 9^{\prime}$ $5^{\prime \prime}$ W Long), Humboldt Bay, California. Marsh material on which the mound or midden rests was sampled at $8 \mathrm{ft}, 8 \mathrm{in}$. below the mound surface. Coll. 1913 by L. L. Loud (1913, p. 266-68) ; subm. by R. F. Heizer, University of California, Berkeley. Comment: it is hoped that this sample will establish a maximal date for the occupation on Gunther Island, as well as for the mound itself.

M-1066. Boarding School Site, Montana

$360 \pm 150$

Charcoal which included rootlets from Blackfoot Indian reservation $\left(48^{\circ}\right.$ $38^{\prime} 18^{\prime \prime} \mathrm{N}$ Lat, $112^{\circ} 57^{\prime} 27^{\prime \prime} \mathrm{W}$ Long), Montana, taken from layer 21 in $\mathrm{S}$ 
wall of square $25 \mathrm{~W} 1$, in a bison-drive site with deep stratification (Kehoe and Kehoe, 1960). Coll. 1952 and subm. by T. F. Kehoe, Saskatchewan Museum of Natural History. Comment: (J.B.G.) this date may be somewhat too recent, because of the rootlets.

\section{E. Mexico}

\section{Santa Marta Cave series, Chiapas, Mexico}

Charcoal from Santa Marta Cave ( $16^{\circ} 48^{\prime} \mathrm{N}$ Lat, $93^{\circ} 23^{\prime} \mathrm{W}$ Long), Chiapas, Mexico. Coll. by R. S. MacNeish and F. A. Petersen; subm. by R. S. MacNeish, National Museum of Canada, Ottawa.

M-977. Santa Marta Cave, level 2

$1870 \pm 200$

Charcoal from square N3E1, level 2, floor 6, zone A. Comment: sample should date the Classic period, remains of the Piedra Parada phase. This should have some relevance to the Maya Calendar problem.

M-978. Santa Marta Cave, level 5

$3280 \pm 200$

Charcoal from square SIE2, level 5, zone C. Comment: should date Chiapa de Corzo, Period I, Early Formative.

\section{M-979. Santa Marta Cave, level 7}

$7320 \pm 300$

Charcoal from square SIE2, level 7, floor 3, zone F. Comment: should date late Santa Marta pre-ceramic complex.

M-980. Santa Marta Cave, level 9

$8730 \pm 400$

Charcoal from square N1E1, level 9, floor 2, zone G. Comment: should date the early Santa Marta complex in this cave.

\section{F. Far East and Pacific}

M-921. Rano Raraku Lake Site, Easter Island

$100 \pm 150$

Totora reeds, Scirpus riparius L., living in freshwater lake of Rano Raraku $\left(27^{\circ} 10^{\prime} \mathrm{S}\right.$ Lat, $109^{\circ} 25^{\prime} \mathrm{W}$ Long $)$, Easter Island. Coll. November 1955 to April 1956 by C. S. Smith, with Thor Heyerdahl; subm. by Smith, Univ. of Kansas, Lawrence. Comment: totora reeds (M-732, $1650 \pm 250$, Michigan IV) were used to date Ahu number 1, Ahu Tepeu Site (E-13), Easter Island (grave 2). Smith considers this too old. A sample of bone (M$870,330 \pm 110$, Michigan V) was subm. from this same site. This specimen, M-92l, was dated to determine the $\mathrm{C}^{1+}$ age of modern reeds. Scientific reports of the Heyerdahl expedition are still in manuscript.

M-689. Eider Point, Aleutians $\quad 890 \pm 150$

Populus driftwood (id. by T. P. Bank, II) from Eider Point $\left(53^{\circ} 57^{\prime} 35^{\prime \prime}\right.$ $\mathrm{N}$ Lat, $166^{\circ} 35^{\prime} 40^{\prime \prime} \mathrm{W}$ Long) a long, low spit forming the western entrance to Unalaska Bay, Unalaska Island, eastern Aleutians. Sample was from SE quad. sec. A, excavation unit \#2, level $6,2.5 \mathrm{ft}$ below datum level which is $2 \mathrm{ft}$ above the basal cobble beach underlying the site. Coll. August 1954 by F. Hadleigh-West; subm. by T. P. Bank, II, Ann Arbor, Michigan. Comment: the site, one of the deepest in the area ( $30 \mathrm{ft}$ of cultural deposits), is quite dif- 
ferent culturally from the Amaknak D Site (Bank, 1953a; 1953b), which is only $5 \mathrm{mi}$ away. The first occupation of Eider Point (M-687, Michigan V, p. 44, from $2 \mathrm{ft}$ above datum line was $740 \pm 150$ ) occurred later than Amaknak D (M-676, M-677, M-678, M-681 and M-682, Michigan IV, p. 193, with dates from 1880 to 1100 B.P.).

\section{G. Continental Old World}

\section{Ereta del Pedregal series, Spain}

Peat from Ereta del Pedregal ( $39^{\circ} 00^{\prime} \mathrm{N}$ Lat, $00^{\circ} 4^{\prime} \mathrm{W}$ Long), Valencia Province, Spain. The bog deposit, $80 \mathrm{~cm}$ thick, lies beneath $150 \mathrm{~cm}$ of clay and above rock. Coll. September 1957 by Josefa Menéndez Amor and F. Florschutz; subm. by Menéndez Amor, National Museum of Natural Sciences, Madrid, Spain.

\section{M-753. Ereta del Pedregal, $160 \mathrm{~cm}$ level}

$3930 \pm 250$

Bog material from the upper $10 \mathrm{~cm}$ of the deposit.

M-754. Ereta del Pedregal, $230 \mathrm{~cm}$ level

$6130 \pm 300$

Bog material from the $230 \mathrm{~cm}$ level of the deposit. Comment: samples date formation of bog, which occurred in Neolithic-Eneolithic-Bronze times. Pollen analysis has produced a diagram in which Quercetum mixtum is dominant, but with fairly high percentages of Pinus; other trees do not exceed $10 \%$. The spectrum at $230 \mathrm{~cm}$ shows predominance of Pinus, followed by Quercetum mixtum, and low percentage of Betula.

\section{M-994. Soto de Medinilla, Spain}

$2175 \pm 200$

Charred wheat from Soto de Medinilla $\left(41^{\circ} 39^{\prime} \mathrm{N}\right.$ Lat, $4^{\circ} 44^{\prime}$ W Long), a Celtic town in isthmus of a large meander of Pisuerga River, a tributary of the Duero, Valladolid, Spain. Specimen came from interior of round-house no. 1 and was found beneath a hearth of the latest Celtic level, which was covered by a Celto-Iberian level. Sample dates a Bronze Age "Celtic Population" which is associated with Celtic town Cortes de Navarra (Ebro). Uppermost Celto-Iberian level continues into layers showing Romanization which occurred in the 2nd century B.c. A comparable specimen of wheat was given to Hans Helbaek of Copenhagen, for study. Coll. October 1957 and subm. by Pedro de Palol, Univ. of Valladolid, Valladolid, Spain.

\section{M-931. Holzhausen Site, Germany $\quad 3560 \pm 250$}

Charcoal from a barrow in the neighborhood of a mound of the singlegrave culture, near Holzhausen $\left(52^{\circ} 49^{\prime} 13^{\prime \prime} \mathrm{N} \mathrm{Lat}, 8^{\circ} 27^{\prime} 52^{\prime \prime}\right.$ E Long), Gemeinde Wildeshausen, Landkreis Oldenburg, Germany. Charcoal was found within a horseshoe-shaped stone arrangement at the former ground surface. The find indicates a cremation, but no grave was discovered. Apparently the body was simply burned and only later mounded over. Two later burials, in the form of cremations, without grave goods, were intruded in the mound built over the burned body. As such bone beds are found primarily from PreChristian Iron Age, the funeral pyre beneaih the mound must be still older, 
i.e. Bronze-Iron Age. Coll. November 1957 and subm. by J. Pätzold, State Museum of Natural Science and Prehistory, Damm 40, Oldenburg, Germany.

M-932. Einen Site, Germany

$2220 \pm 150$

Charcoal from Einen Site $\left(52^{\circ} 49^{\prime} 13^{\prime \prime} \mathrm{N}\right.$ Lat, $8^{\circ} 27^{\prime} 52^{\prime \prime}$ E Long),

Geimeinde Goldenstedt, Kreis Vecta, Germany, from a cremation at ground level at Point I. A small, round barrow was erected over this funeral pyre. An embankment was constructed over this mound and a further covering of earth extends over this embankment. Burned bones, and iron fittings from ornaments of a shield, were found between the pieces of charcoal. On the basis of these finds, the burial was thought to date around 500 B.c. The last covering over the mound has been dated (by secondary burials) between 500 and 200 B.c. This brackets the age of the embankment, the secondary burials being younger, and the original burial older.

\section{Safadi Site series, Israel}

Safadi Site is a subterranean village, dug in the alluvial sandy loam forming the upper part of the Wadi Sheba Terrace, near Beersheba $\left(31^{\circ} 13^{\prime} 30^{\prime \prime}\right.$ $\mathrm{N}$ Lat, 34 $4^{\circ} 46^{\prime} 45^{\prime \prime}$ E Long), Israel. The culture discovered at Safadi is intrusive in Palestine and localized in Jordan Valley and the southern portion of the country. Samples coll. 1954 and 1955 and subm. by Jean Perrot, Directeur, Mission Archeologique Francaise en Israel.

M-864B. Safadi, 1.5-m level

$\mathbf{5 2 7 0} \pm \mathbf{3 0 0}$

Burnt wood (terebinth ?), (original sample 346), from locus 318, was associated with fireplace in open pit house, $1.5 \mathrm{~m}$ below present surface. From the same archaeologic level as M-864A.

M-864C. Safadi, 1.8-m level

$\mathbf{5 1 2 0} \pm \mathbf{3 5 0}$

Burnt wood (terebinth ?), (original sample 320) from locus 325 , a bellshaped silo, $1.8 \mathrm{~m}$ below surface. May be later than samples 346 and 693 , but total duration of the occupation of the site does not exceed 200 to $300 \mathrm{yr}$.

M-864A. Safadi, 3.0-m level

$5420 \pm 350$

Burnt wood (terebinth ?), (original sample 693), from locus 309, on floor of a subterranean passage ca. $3 \mathrm{~m}$ below the surface. This is considered the best specimen, since at this level there was no possibility of contamination by roots. Comment: Perrot believes that the Beersheba people were the first Armenoids to make their appearance in the Middle East and that they introduced copper metallurgy into Palestine. His estimate for Beersheba culture at Safadi was 3500 to 3000 B.c. (Perrot, 1955; 1957).

\section{Zimbabwe Acropolis series, Africa}

Charcoal from acropolis on Zimbabwe Hill $\left(20^{\circ} 15^{\prime} \mathrm{S}\right.$ Lat, $30^{\circ} 56^{\prime} \mathrm{E}$ Long), Southern Rhodesia, Africa. Dates the Iron Age of Southern Rhodesia. Coll. 1958 by E. R. Robinson, National Museum of Southern Rhodesia; subm. by Roger Summers, National Museum, Bulawayo, Southern Rhodesia. Reported by Summers (1955). 
M-913. Zimbabwe Acropolis, lowest level

$1630 \pm 150$

The deepest charcoal specimen (former no. 58452) dates the end of earliest Southern Rhodesia Iron Age cultures, and the beginning of Iron Age cultures associated with mining. Expected to date 1500 B.P.

M-914. Zimbabwe Acropolis, middle level

$875 \pm 150$

Charcoal from middle level (former no. 58403), associated with a change in ceramic style; provides the earliest possible date for walling at Zimbabwe. Estimated to date 1000 B.P.

M-915. Zimbabwe Acropolis, highest level

Charcoal from the highest level (former no. 58355) where a second change in ceramic style occurs; dates the end of early walling phase and beginning of the period associated with the best quality walling (Type Q). Expected to date 17th century A.D.

Date lists:

$\begin{array}{ll}\text { Arizona II } & \text { Shutler and Damon, 1959 } \\ \text { Isotopes I } & \text { Walton, Trautman and Friend, 1961 } \\ \text { Michigan I } & \text { Crane, 1956 } \\ \text { Michigan II } & \text { Crane and Griffin, 1958a } \\ \text { Michigan III } & \text { Crane and Griffin, 1958b } \\ \text { Michigan IV } & \text { Crane and Griffin, 1959 } \\ \text { Michigan V } & \text { Crane and Griffin, 1960 } \\ \text { USGS IV } & \text { Rubin and Alexander, 1958 }\end{array}$

Alden, W. C., 1918, The Quaternary geology of southeastern Wisconsin: U. S. Geol. Survey Prof. Paper, no. 106, 356 p.

Bank, T. P. II, 1953a, Cultural succession in the Aleutians: Am. Antiquity, v. 19, p. 40-49. $246-264$.

Bastian, Tyler, 1958, The Beloit College mound group-a preliminary report: Wisconsin Archeologist, v. 39 , p. 155-173.

Bluhm, E. A., and Beeson, W. J., 1960, The excavation of three Hopewell mounds at the Caterpillar Tractor Company, in Indian mounds and villages in Illinois: Illinois Archaeol. Survey Bull. 2, p. 1-24.

Broyles Bettye, 1958, Russell Cave in northern Alabama: Tennessee Archaeol. Soc. Misc. Paper $4,35 \mathrm{p}$.

Butler B R. 1958, Microblades and polyhedral cores from a central Washington site: Washington Archaeologist, v. 2, no. 10, p. 3-9.

Carter, G. F., 1958, Archaeology in the Reno area in relation to the age of man and the cultural sequence in America: Am. Philos. Soc. Proc., v. 102, p. 174-192.

Chapman, D H. 1957, A report of progress: archaeological research of the University of Missouri, 1955-1956: Columbia, Missouri Archaeol. Soc., spec. pub., 57 p.

Crane, H. R., 1956, University of Michigan radiocarbon dates I: Science, v. 124, p. $664-$ 672. v. 3, p. 46 .

Crane, H. R., and Griffin, J. B., 1958a, University of Michigan radiocarbon dates II: Sci-

ence, v. 127, p. 1098-1105. 1123.

Supp., v. 1, p. 173-198. 1960, University of Michigan radiocarbon dates V: Am. Jour. Sci. Radioc. Supp. v. 2, p. 31-48.

Downs, Theodore, 1949, Pleistocene avifauna from Kansas and its environment: [abs.] Geol. Soc. Am. Bull., v. 60, p. 1949-1950. 
221

1954, Pleistocene birds from the Jones fauna of Kansas: Condor, v. 56, p. 207.

Dragoo, D. W., 1958, Cult of the dead: Carnegie Institute Mag., v. 32, p. 313-315.

p. $134-144$

1959a, An unusual cache of Adena tablets: Pennsylvania Archaeologist, v. 29 1959 ogist, no. 11 , p. $3-8$

Ford, T. L., 1958, Adena traits in Maryland: Eastern States Archeol. Fed. Bull., no. 17, p. 10-11.

Foster, Z. C., and Shearin, A. E., 1939, Soil survey of Cheboygan County, Michigan: U. S. Dept. Agriculture, ser. 1934, no. 15, p. 47

Fowke, Gerard, 1902, Archaeological history of Ohio: Ohio State Archaeol. and Hist. Soc., XVI-760., p. 362-368. Rept., p. 399-540. ( Agogino, G. A., 1959, Archaic and Paleo-Indian archaeological discoveries in western Iowa: Texas Jour. Sci., v. 11, no. 4, p. 482-491.

Greenman, E. F., 1926, Michigan mounds, with special reference to two in Missaukee County: Michigan Acad. Sci., Arts and Letters Papers, v. 7, p. 1-9.

1932, The excavation of the Coon mound and an analysis of the Adena culture: Ohio Hist. Quart., v. 41, p. 369-523.

Griffin, James B., 1943, The Fort Ancient aspect: Its cultural and chronological position in Mississippi valley archaeology: Ann Arbor, University of Michigan Press, $392 \mathrm{p}$.

Guilday, J. R., and Bender, M. S., 1958, A recent fissure deposit in Bedford County, Pennsylvania: Carnegie Mus. Annals, v. 35, p. 127-138.

Heizer, R. F., and Elsasser, A. B., 1953, Some archaeological sites and cultures of the central Sierra Nevada: California Univ. Archaeol. Survey Rept., no. 21, 42 p.

Heizer, R. F., and Krieger, A. D., 1956, The archaeology of Humboldt Cave, Churchill County, Nevada: California Univ. Pub., Am. Archaeology and Ethnology, v. 47, p. $1-190$.

Hopkins, M. L., 1951, Bison (Gigantobison) latifrons and Bison (Simobison) alleni in southeastern Idaho: Jour. Mammalogy, v. 32, no. 2, p. 192-197.

Jour 1955, Skull of fossil camelid from American Falls lake bed area of Idaho: Jour. Mammalogy, v. 36, no. 2, p. 278-282.

Hough, J. L., 1958, Geology of the Great Lakes: Urbana, University of Illinois Press, $313 \mathrm{p}$.

Jennings, J. D., 1957, Danger Cave: Soc. Am. Archaeology Mem., 14, 328 p.

Keel, B. C., 1960, The Money's Bend site, Ce'3, Cherokee County, Alabama: Florida Anthropologist, v. 13, no. 1, p. 1-16.

Kehoe, R. F., and A. B., 1960, Observations on the butchering technique at a prehistoric bison kill: Am. Antiquity, v. 25, no. 3, p. 421-423.

Kelly, A. R., and Larson, L. H., Jr., 1957, Explorations at Etowah Indian mounds near Cartersville, Georgia, 1954-56: Archaeology, v. 10, p. 39-48.

Lewis, T. M. N., and Kneberg, M., 1946, Hiwassee Island: an archaeological account of four Tennessee Indian peoples: Knoxville, University of Tennessee Press, 188 p.

Loud, L. L., 1913, Ethnography and archaeology of the Wiyot territory: California Univ. Pub. Am. Archaeology and Ethnology, v. 14, p. 225-437.

Miller, C. F., 1958, Russell Cave: new light on stone age life: Nat. Geog. Mag., v. 113, no. 3, p. 426-437.

Oehler, C. M., 1950, Turpin Indians. A report on the findings of the Cincinnati Museum of Natural History's archaeological exploration of the Turpin site, Hamilton County, Ohio, 1946-1949: Cincinnati Mus. Nat. History, Pop. Pub. Ser., no. 1, 36 p.

Patzold, J., 1958, Dreischichtiger grabhugel der einzelgrab-kultur bei Holzhausen, Gmd. Wildeshausen (Oldb.) : Nachrichten aus Niedersachsens Urgeschichte, nr. 27. Perrot, J., 1955, The excavations at Tell Abu Matar, near Beersheba: Israel Explor. Jour.,
v. 5, no. 1, p. 17-261. p. 8-15. 1959, The dawn of history in southern Palestine: Archaeology, v. 12, no. 1

Porter, T., and McBeth, D., 1956, Exploration of an Adena mound: Ohio Archaeologist, v. 6 , p. $94-98$

106-110. 1957, Preliminary report on the West mound: Ohio Archaeologist, v. 7, p.

1958, Report on the West mound: Ohio Archaeologist, v. 8, p. 28-31. 
Ritchie, W. A., 1932, The Lamoka Lake site: New York State Archaeol. Assoc., Researches and Trans., v. 7 , no. 4.

Robbins, Maurice, 1960, Wapanucket No. 6: and archaic village in Middleboro, Massachusetts: Cohannet Chap., Massachusetts Archaeol. Soc., Inc., 112 p.

Rubin, Meyer, and Alexander, Corrinne, 1958, U. S. Geological Survey radiocarbon dates IV: Science, v. 127, p. 1476-1487.

Ruppé, R. J. 1956, Notes and News: Am. Antiquity, v. 21, p. 449-450.

Shutler, Dick, Jr., and Damon, P. E., 1959, University of Arizona radiocarbon dates II: Am. Jour. Sci. Radioc. Supp., v. 1, p. 59-62.

Starr, S. F., 1960, The archaeology of Hamilton County, Ohio: Cincinnati Mus. Nat. Hist. Jour., v. 23, no. 1, p. 1-130.

Summers, R., 1955, The dating of the Zimbabwe ruins: Antiquity, v. 29, p. 107-130.

Swanson, E. H., 1959, A basalt quarry in northeastern Oregon: Tegiwa, Idaho State Coll., v. 2 , no. 1 .

Tihen, J. A., 1942, A colony of fossil neotonic ambystoma tizunum: Kansas Univ. Sci. Bull., v. 28 , p. $189-198$.

Walton, Alan, Trautman, M. S., and Friend, J. P., 1961, Isotopes, Inc. radiocarbon measurements I: Radiocarbon, v. 3, p. 47-59.

Webb, W. S., 1938, An archaeological survey of the Norris basin in eastern Tennessee: U. S. Bur. Am. Ethnology Bull. 118 .

Webb, W' S., and Baby, R., 1957, The Adena people no. 2: Columbus, Ohio State University Press, $120 \mathrm{p}$

Webb, W. S., and Snow, C. R., 1945, The Adena people: Kentucky University Anthropology Archaeology Repts., v. 6, 369 p. 